\title{
Skin Immunity
}

\author{
Agata Matejuk $^{1,2}$ (1)
}

Received: 14 November 2016/ Accepted: 20 March 2017/Published online: 16 June 2017

(c) The Author(s) 2017. This article is an open access publication

\begin{abstract}
Skin is the largest organ of the body with a complex network of multitude of cell types that perform plastic and dynamic cellular communication to maintain several vital processes such as inflammation, immune response including induction of tolerance and disease prevention, wound healing, and angiogenesis. Of paramount importance are immunological functions of the skin that protect from harmful exposure coming from external and internal environments. Awareness of skin immunity can provide a better comprehension of inflammation, autoimmunity, cancer, graft-versus-host disease, vaccination, and immunotherapy approaches. This paper will update on what we currently know about immune sentinels contributing to skin immunity.
\end{abstract}

Keywords Immune response - Skin · Epidermis ·

Dermis · Hypoxia

\section{Introduction}

The skin is not only a physical barrier between external and internal environments actively protecting from stress caused by injury, microbial treat, UV irradiation, and environmental toxins. For a long time, skin was envisioned only as a static shield separating from external milieu. The concept of skin immunity and skin-associated lymphoid tissue was

Agata Matejuk

amatejuk@hotmail.com

1 Faculty of Health Science, Wroclaw Medical University, Wrocław, Poland

2 Faculty of Science and Technology, Karkonosze College, Jelenia Góra, Poland introduced by Streilein (1983) and this concept, although with caution, has been further extended to nominate skin as a peripheral lymphoid organ (Egawa and Kabashima 2011; Ono and Kabashima 2015). Immune system within the skin is located in both major structural compartments: epidermis and dermis and consist of several important types of immunocompetent cells. Main skin-resident immune cells, Langerhans cells (LCs) together with melanocytes that produce melanin, occupy epidermis, whereas the other types of immune specialized cells such as various dendritic cell (DCs) subpopulations, macrophages, and several $\mathrm{T}$ cell types reside in deeper layer-dermis. The effectiveness of the skin immune system strongly depends on the close interplay and communication between immune cells and the skin environment, e.g., neighboring keratinocytes and fibroblasts. Direct functional success of the skin immunity depends also on the flexibility of dermal vessels and the lymph nodes that drain the skin. This complex network ensures the proper surveillance and communication on which the elimination of external threat relies on. Homeostasis ends when skin function and integrity are challenged and disease starts when homeostasis is irreversibly compromised.

During the last years, a new contribution in immune response for several populations of cells residing different layers of the skin has emerged. In this paper, the role of different cellular populations that may change the fate of skin immunity is discussed.

\section{Immune Competence in Epidermis}

\section{Keratinocytes}

Keratinocytes constitute a major structural element of outer layer of the skin and depending on the maturation level 
create four strata of epidermis. Besides their structural character, recent studies found unexpected role for keratinocytes in innate and adaptive immunity (Nestle et al. 2009). Modulation of the immune system and the skin immune status strongly depends on functional keratinocytes. Keratinocytes together with neutrophils and epithelial cells create a major source of antimicrobial peptides (AMPs), small cationic and amphipathic molecules, acting as a first line of defense (Harder et al. 1997; Matejuk et al. 2010). Aberrant AMPs expression leads to the development of inflammatory skin diseases and susceptibility to microbial infections. Defective function of some AMPs such as cathelicidin and $\beta$-defensins may play a role in atopic dermatitis lesions (Wollenberg et al. 2011). Decreased AMP expression leads to increased predisposition to skin infections in atopic dermatitis, whereas high expression of AMPs is observed in psoriatic lesions (de Jongh et al. 2005; Ong et al. 2002). It has been found that cathelicidin coupled with self-DNA activates plasmocytoid DCs, key players in the pathogenesis of psoriasis (Lande et al. 2007). Expression of AMPs can be upregulated by some pro-inflammatory cytokines such as interleukin IL-17 and IL-22 (Liang et al. 2006). Recently, it has been shown that the cholinergic anti-inflammatory pathway via acetylcholine downregulates AMPs (Curtis and Radek 2012). One of AMPs, a member of cathelicidin family (LL37 ), produced by keratinocytes has an essential role in promoting angiogenesis and wound healing (Zanetti 2004). Injury increases levels of LL-37 and this process is dependent on active and functional form of vitamin D3 (Schauber et al. 2007). Keratinocytes express on the surface and within, endosomes Toll-like receptors (TLRs). Activation of TLRs on keratinocytes promotes Th1 responses and production of interferons (IFNs) (Miller 2008). Keratinocytes are able to generate the production of classic pro-inflammatory cytokines such as IL- $1 \beta$ and IL18 via inflammasome signalling pathway (Martinon et al. 2009). Inflammasome, a pro-inflammatory machinery, was found to be activated by UV irradiation (Feldmeyer et al. 2007; Keller et al. 2008). IL-1 produced by keratinocytes can upregulate expression of intercellular adhesion molecule (ICAM)-1. Upregulation of adhesion molecules on dermal endothelial cells and MHC class II on keratinocytes and LCs facilitate leukocyte trafficking into the skin. Besides IL-1 and IL-18, keratinocytes are able to produce IL-6, IL-10, and tumor necrosis factors (TNFs). Moreover, plasticity of keratinocytes in production of chemokines and chemokine receptors empowers them to communicate and cooperate with other cell types during immune response. In disease conditions with abundant infiltration of $\mathrm{T}$ cells such as psoriasis, keratinocytes express several chemokine ligands such as CXCL9, CXCL10, CXCL11, and CCL20 (Albanesi et al. 2005). The latter selectively attracts precursors of LCs into epidermis (Dieu-Nosjean et al. 2000). Upregulated levels of CXCL1 and CXCL8 by keratinocytes signal neutrophils for epidermis infiltration (Albanesi et al. 2005). Studies on graft-versus-host disease revealed that keratinocytes upon stimulation with IFN- $\gamma$ can express MHC class II, thus may play a role as antigenpresenting cells (APCs) for T cell infiltrates (Nickoloff and Turka 1994). Keratinocyte involvement in crosstalk with T cells is evident. Studies show that depending on the stimuli and cellular environment, keratinocytes possess ability to induce $\mathrm{T}$ cells activation or antigen-specific tolerization. Keratinocytes are not able to prime naïve $\mathrm{T}$ cells; however, they can stimulate antigen experienced CD4 and CD8 cells (Black et al. 2007). Malfunction of keratinocytes leads to pathological conditions such as autoimmunity and cancer. With upregulation of CD40 ligand on keratinocytes, the number of LCs drastically decreases and the number of dermal DC (dDC) increases with a strong effect on tolerance disruption to skin antigens (Mehling et al. 2001). Redistribution of LCs and $\gamma \delta$ cells in skin caused by acute as well as constitutive expression of retinoic acid early transcript 1 on keratinocytes can directly lead to cancer (Jones et al. 2008; Oppenheim et al. 2005). Interestingly, Notch1 a proto-oncogene expressed by most cancers has adverse consequences in epidermis (Koch and Radtke 2007). Reduction in Notch signalling within keratinocytes leads to defective skin barrier and development of skin tumors upon exposure to UV radiation (Demehri et al. 2009).

\section{Langerhans' Cells}

Considering the localization of LCs which is the outer part of the skin in comparison with other types of DCs suggests their role as first line fighters. Recent studies, however, confirm the involvement of LCs in tolerogenic responses rather than those promoting inflammation (Kaplan et al. 2008; Shklovskaya et al. 2011). Suppressive effects of LCs on contact hypersensitivity depend on their IL-10 production and induction of $\mathrm{CD}^{+}$regulatory $\mathrm{T}$ cells (Yoshiki et al. 2009) and tolerizing $\mathrm{CD}^{+} \mathrm{T}$ cells (Gomez de Aguero et al. 2012). Nevertheless, the role of LCs in skin immune responses stays somewhat enigmatic. For a long time, lectin Langerin (CD207) that induces the formation of Birbeck granules, characteristic structures for LCs, served as a marker for human and murine LCs (Valladeau et al. 2000). Recently, Langerin has also been shown to be expressed by $\mathrm{dDC}$ which constitutes distinct population of cells (Ginhoux et al. 2007; Nagao et al. 2009; Poulin et al. 2007) and is characteristic for most connective and mucosal tissues and co-exists with classic DCs Langerin negative. Besides Langerin, Langerhans cells can be recognized by other markers such as CD45, MHC class II 
molecules, E-cadherin, and epithelial-cell adhesion molecule (Borkowski et al. 1996; Stingl et al. 1980; Tang et al. 1993). CD1a molecule is exclusively expressed on human, but not murine LCs (Romani et al. 2006) and is able to present microbial nonpeptide antigens to $\mathrm{T}$ cells (Hunger et al. 2004). Mannose receptor CD206 distinguishes a subset of inflammatory dendritic epidermal cells from LCs (Guttman-Yassky et al. 2007). Interesting feature of LCs in the steady state is their ability to repopulate locally independently on the circulating precursors (Stoitzner et al. 2005). Their migratory rate through the dermal lymphatic vessels to the skin-draining lymph nodes increases during inflammation (Nishibu et al. 2006). Upon stimulation, LCs elongate their dendrites that enter epidermal tight junctions to capture antigens (Kubo et al. 2009). They maturate and finally localize in the $\mathrm{T}$ cell area by upregulating $\mathrm{MHC}$ class II molecules, co-stimulatory molecules (CD40), and essential for migration CCR7 chemokine receptor (Larsen et al. 1990; Ohl et al. 2004; Pierre et al. 1997). LCs are crucial for capturing protein antigens and mediation of Th2 local environment. Permanent LCs depletion results in decreased IgE serum levels (Nakajima et al. 2012). LCs have been found to be superior to dDCs in effective CD70mediated $\mathrm{CD}^{+} \mathrm{T}$ cells responses to virus, with little or no effect on bacteria (van der Aar et al. 2011). However, it seems that both LCs and dDCs can resemble each other upon inflammatory reactions (Noordegraaf et al. 2010; Zahner et al. 2011) and the outcome of immune response most likely depends on the number and not the type of DCs (Romani et al. 2010). Except for hypersensitivity skin inflammation models such as cutaneous leishmaniasis, LCs are negative immune regulators (Kautz-Neu et al. 2011). The most recent studies show that in case of Candida albicans infection, the morphology of the pathogen dictates the proper responses by LCs or dDC subsets (Igyarto et al. 2011; Kashem et al. 2015).

\section{Immune Competence in Dermis}

\section{Dermal DCs}

In contrast to LCs that occupy epidermis, $\mathrm{dDCs}$ reside in dermis below the epidermal-dermal junction, and are distinguished by the expression of epithelial-cell adhesion molecule, IL-10, and ability to stimulate B cells into plasma cells secreting IgM (Dubois et al. 1999). Expression of low-density lipoprotein-related protein 1 (or CD91) is also characteristic for dDCs (Boyman et al. 2005). The plasticity of dDCs is remarkable and depending on the function, sublocalization, and environment, they create phenotypically diverse group of cells (Henri et al. 2010; Malissen et al. 2014; Tamoutounour et al. 2013). The main two types of dDCs are: Langerin ${ }^{+} \mathrm{CD} 103^{+} \mathrm{DCs}$, which are similar to mouse $\mathrm{CD}^{+}$cross-presenting DCs in lymphoid organs (Bedoui et al. 2009) and Langerin negative dDCs. Within the latter, at least three DCs populations were identified in the murine dermis: monocytes-derived DCs with $\mathrm{CCR} 2{ }^{+} \mathrm{CD} 64^{\text {low/+ }}$ phenotype and two populations of dermal conventional DCs that originate from blood-borne precursors: a subpopulation with $\mathrm{CD} 11 \mathrm{~b}$ expression and the double negative XCR $1^{-} \mathrm{CD} 11 \mathrm{~b}^{-}$subpopulation (Auffray et al. 2009; Lopez-Bravo and Ardavin 2008). Dermal DCs can persist in immature state with expression of TLR2, TLR4, CD206, and CD209 (Angel et al. 2007) or mature state with expression of CD83 co-stimulatory molecule and low levels of TLRs. Main role for dDCs is to provide immunosurveillance against pathogens by participation in inflammatory responses via arranging efficient cytokine and chemokine network (Guttman-Yassky et al. 2007). DCs that produce both TNF- $\alpha$ and iNOS might play a major role in psoriasis induction (Lowes et al. 2005; Serbina et al. 2003). In addition, the positive correlation between IL-23/IL-17/IL-22 axis and psoriasis development has been demonstrated (Krueger et al. 2007; Leonardi et al. 2008; Zaba et al. 2007a). However, there is a controversy which subset of DCs is a key player in psoriasis (Glitzner et al. 2014; Wohn et al. 2013; Yoshiki et al. 2014). Tortola et al. (2012) identified IL-36, a novel member of IL-1 family that allows DCs-keratinocytes crosstalk during IL23/IL-17/IL-22-dependent immune responses. It has also been found that in psoriasis, an important role plays LL37, an AMP that breaks tolerance to self-DNA (Lande et al. 2007). This triggers (infrequent in healthy skin) plasmocytoid DCs, strong producers of type I IFNs (Nestle et al. 2005). In consequence, myeloid DCs are activated and adaptive immune responses are induced (Boyman et al. 2007). It has been found that DCs and tissue-resident macrophages have common precursors. Inflammatory monocytes with $\mathrm{CD} 115^{+} \mathrm{LY}_{6 \mathrm{C}^{+}} \mathrm{LY} 6 \mathrm{G}^{+} \mathrm{CCR} 2^{+}$phenotype differentiate into inflammatory DCs and monocytes with $\mathrm{LY}^{-} \mathrm{CH}^{-} \mathrm{LG}^{-} \mathrm{CX} 3 \mathrm{CR} 1^{+}$phenotype transform into activated macrophages in mice; in humans, inflammatory monocytes belong to $\mathrm{CD} 14^{+} \mathrm{CD} 16^{-}$circulating monocytes (Auffray et al. 2009). A subpopulation of dDCs, macrophage-like cells expressing factor XIIIa and CD163 typical for macrophages, might play a key role in wound healing (Zaba et al. 2007b). The complexity of the network created by dendritic cells, monocytes, and macrophages in the skin assures effective immunosurveillance and highly diverse immune response.

\section{Mast Cells}

Mast cells are mainly located in the upper dermal part of the skin, where they can easily encounter, respond, and 
protect from infections, venoms, and stress caused by wound healing. Mast cells contain histamine and traditionally are known as typical allergy cells. Nevertheless, recent studies prove their remarkable internal and external plasticity and critical role in vital processes such as wound healing, skin inflammation, angiogenesis, immune tolerance, and cancer (Galli and Tsai 2010; Moon et al. 2010; Tsai et al. 2011). In the human skin, there is a prevalence of mast cells TC type (tryptase positive, chymase positive) which is the richest in proteinase content. Besides tryptase, they contain chymase, carboxypeptidase, and a cathepsin G-like proteinase (Douaiher et al. 2014; Weidner and Austen 1993). Tryptase works on fibronectin and by degrading extracellular matrix proteins (Kaminska et al. 1999) allows immune cells such as neutrophils, mononuclear cells, and lymphocytes to invade epidermis. Its function in the activation and recruitment of the immunecompetent cells ( $\mathrm{Li}$ and $\mathrm{He}$ 2006; Malamud et al. 2003; Wang and He 2006) is further confirmed by its activatory effects on keratinocytes and metalloproteinases (Buddenkotte et al. 2005; Iddamalgoda et al. 2008; Sharlow et al. 2000). The enzyme has also strong proangiogenic activity (Blair et al. 1997). Similar pro-inflammatory action is characteristic for another potent mast cell enzyme, chymase. Chymase has been shown to attract and activate several immune cells (He and Walls 1998; Terakawa et al. 2006) and increase inflammation by its effect on IL-1 $\beta$ and IL-18 (Mizutani et al. 1991; Omoto et al. 2006). In addition to mast cells plasticity, both enzymes were found to downregulate immune response by ability to disintegrate several pro-inflammatory factors such as cytokines and chemokines (Pang et al. 2006; Zhao et al. 2005). Besides indirect modulation of immune response by mast cells via secreted enzymes, they also affect immune-competent cells by direct cell-cell contact or cytokines. Their strong influence on different subpopulations of $\mathrm{T}$ cells including regulatory $\mathrm{T}$ cells (Treg) was observed via mast cells expression of OX-40L and TNF- $\alpha$ production (Nakae et al. 2005; Piconese et al. 2009). OX-40L positive mast cells and their production of TNF- $\alpha$ in combination with T cells derived IL-6 create classic milieu for tissue inflammation. In chronic skin inflammation such as psoriatic lesion and atopic dermatitis, mast cells secrete other cytokines such as IL-4 and/or IFN- $\gamma$ that shape the immune response (Ackermann et al. 1999; Horsmanheimo et al. 1994). In cancer, mast cells can express CD30L (Molin et al. 2001) leading to uncontrolled immune response. Besides known FceRI receptor involved in allergic response, skin mast cells also express Fc $\gamma$ RI and Fc $\gamma$ RIIa receptors involved in $\operatorname{IgG}$ responses (Malbec and Daeron 2007; Zhao et al. 2006). Biological responses of mast cells depend on the balance between positive and negative signals that are generated in FcR complexes (Malbec and Daeron 2007). Another level of communication with other cells and pathogen antigens can be achieved by mast cells via expression of TLRs (Dawicki and Marshall 2007). Additional level of complexity and further involvement of mast cells in immune system are demonstrated by fact that they can behave and function like professional APCs. First, they can express MHC class I and class II; second, they facilitate antigen presentation by expression of co-stimulatory molecules such as CD80 and CD86; and third, they can migrate to lymph nodes, where they further affect $\mathrm{T}$ cells gathering (Frandji et al. 1996; Hershko and Rivera 2010; Wang et al. 1998). Moreover, close interaction between mast cells and professional APCs such as DCs and LCs is essential for APCs to migrate, maturate, and present the antigen. This effect is linked to TNF- $\alpha$ and histamine produced by mast cell as well as their ability to accumulate exogenous antigens within endosomes (Kitawaki et al. 2006; Skokos et al. 2003; Suto et al. 2006). Recently, it has been shown that mast cells can shape and regulate immune response by ability to induce immune tolerance. A key player in this tolerance induction is anti-inflammatory cytokine IL-10 and to the laser extent transforming growth factor (TGF)- $\beta$ released by mast cells. IL-10 has been shown to inhibit inflammatory skin reaction in contact hypersensitivity and UV-induced immunosuppression (Biggs et al. 2010; Byrne et al. 2008). The latter can be explained by UV effect on inhibition of germinal center formation and $\mathrm{T}$ helper $(\mathrm{Th})$ function which in combination with IL-10 derived from mast cells creates immunosuppressive environment (Chacon-Salinas et al. 2011). Mast cells were shown to increase number of regulatory $\mathrm{T}$ cells $\left(\mathrm{CD} 4^{+} \mathrm{CD} 25^{+} \mathrm{Foxp}^{+}\right)$via TGF- $\beta$-dependent mechanism (Zhang et al. 2010). The ability of mast cells to induce immunosuppression and angiogenesis as well as rearrangement of extracellular matrix is pivotal for their role in cancer. In skin cancer caused by UV irradiation, mast cells can be effectively attracted by upregulation of Kit receptor and tumor derived stem-cell factor (SCF) (Huttunen et al. 2002). The importance of Kit-SCF interaction for carcinoma perseverance was further documented in hepatocarcinoma, where increase in number of $\mathrm{CD} 11 \mathrm{~b}$ positive myeloid-derived suppressor cells and regulatory T cells as well as their IL-9 production was observed (Huang et al. 2008; Yang et al. 2010).

\section{T Cell Subsets}

It is not a common knowledge that the skin is a reservoir of approximately 20 billion $\mathrm{T}$ cells, nearly twice the number present in the entire blood volume (Clark et al. 2006). Initially, the perception of skin immunosurveillance was based on $\mathrm{T}$ cells that migrate between skin-draining lymph nodes and peripheral tissues. Local defective migration of 
specific $\mathrm{T}$ cells rather than systemic decline in T-cell-mediated immunity is responsible for weaker DTH responses to bacterial, fungal, and viral antigens (Agius et al. 2009). Studies show that decrease in TNF- $\alpha$ secretion by macrophages inhibits activation of endothelial cells by suppression of E-selectin, vascular cell adhesion molecule, and ICAM expression, thus transmigration of $\mathrm{T}$ cells into the skin (Agius et al. 2009). However, the resident rather than recruited $\mathrm{T}$ cells creates skin immune homeostasis. $\mathrm{T}$ cell skin homing properties are obtained after imprinting process based on contact with skin DCs and mesenchymal cells (Edele et al. 2008; Mora et al. 2005). Some significant role in this process is attributed to vitamin D (Sigmundsdottir and Butcher 2008). Vitamin D has been found to inhibit effector $\mathrm{T}$ cell reactivity and induce regulatory $\mathrm{T}$ cells and their homing to sites of inflammation based on its critical role in AMPs production (Baeke et al. 2011). Epidermal CD $8^{+} \alpha \beta$ T cells are of memory phenotype (Bos et al. 1987) and live among keratinocytes with preferential localization near LCs (Foster et al. 1990). Equal numbers of $\mathrm{CD}^{+}$and $\mathrm{CD}^{+}{ }^{+}$cells restricted to capillaries and the epidermal-dermal junction are characteristic for dermis (Mueller et al. 2013; Nomura et al. 2014). Most of them are memory cells expressing cutaneous lymphocyte-associated antigen. Skin memory $\mathrm{T}$ cells hold strategic position and create the first line of defense against pathogen challenge (Schenkel and Masopust 2014). They express CD103 and very late antigen 1 and after infectious recall undergo homeostatic proliferation (Gebhardt et al. 2009). Th17 together with Th1 and Th2 cells are important effector cells in inflammatory skin pathology such as allergic inflammation (Boyman et al. 2004; Conrad et al. 2007; Honda et al. 2013; Kim et al. 2013) or psoriasis (Conrad et al. 2007). IL-17 together with IL-22 produced by Th17 cells have well-documented role in psoriasis by inducing abnormal differentiation of keratinocytes. Nevertheless, Th17 cells protect skin from bacteria and fungi such as Candida albinos, Klebsiella pneumonia, and Staphylococcus aureus (Kashem et al. 2015; Kurebayashi et al. 2013). The magnitude of immune responses in skin is efficiently controlled by regulatory $\mathrm{T}$ cell (Tregs). They comprise of 5-10\% of all resident skin T cells (Clark et al. 2006; Vukmanovic-Stejic et al. 2008). Together with other resident $\mathrm{T}$ cells, Tregs actively circulate between the skin and lymph nodes not only during immune response but also in the steady state (Clark 2010; Tomura et al. 2010). They can regulate T cell responses, function of APCs such as DCs and macrophages as well as neutrophil accumulation during early stages of inflammation (Richards et al. 2010; Schwarz and Schwarz 2010; Tiemessen et al. 2007). Tregs have been shown to induce anti-inflammatory functional profile in macrophages and inhibit macrophage TNF- $\alpha$ production (Tiemessen et al. 2007). It has been well documented that immunosuppression by Tregs is directly related to cancer. Primary and metastatic melanoma contain significant numbers of suppressor $\mathrm{T}$ cells, and in human squamous cell carcinoma of the skin, $50 \%$ of T cells are Foxp3 positive (Ahmadzadeh et al. 2008; Clark et al. 2008; Kaporis et al. 2007). Topical treatment with the TLR7 agonist increased E-selectin expression and reduced function and abundance of Tregs (Clark et al. 2008). Foxp $^{+}$Treg depletion induced partial regression of established B16 melanoma in mice and accumulation of cytotoxic $\mathrm{CD}^{+} \mathrm{T}$ cells (Klages et al. 2010). Tregs were shown to inhibit Fas ligand-induced innate and adaptive tumor immunity in similar model and their removal improved tumor rejection (Simon et al. 2007).

Unconventional or innate resident $\mathrm{T}$ cells belong to $\gamma \delta \mathrm{T}$ cells and NKT cells (Hayday and Tigelaar 2003; Kronenberg 2005). Unlike naïve $\alpha \beta$ T lymphocytes, skin $\gamma \delta$ T cells reside in the epidermis in a pre-activated state. In mice, $90 \%$ of all $\mathrm{T}$ cells in epidermis are $\mathrm{V} \gamma 5^{+}$dendritic epidermal $\mathrm{T}$ cells (Bergstresser et al. 1985). They provide immunoregulation and control over $\alpha \beta$ T-cell-mediated inflammation (Boyden et al. 2008; Girardi 2006). In contrast to $\alpha \beta \mathrm{T}$ cells, $\gamma \delta \mathrm{T}$ cells inhibit skin tumor responses (Girardi et al. 2001, 2002; Roberts et al. 2007). Human $\gamma \delta$ $\mathrm{T}$ cells are attributed to the regulation of epithelial homeostasis, cutaneous malignancy, and contact hypersensitivity (Holtmeier and Kabelitz 2005). Recent finding shows that IL-23 responsive dermal $\gamma \delta \mathrm{T}$ cells are the major IL-17 producers and may represent a novel target for the treatment of psoriasis (Cai et al. 2011). Moreover, skin $\gamma \delta \mathrm{T}$ cells act as primary responders to damage and wound repair due to their ability to produce growth factors participating in wound repairing (Toulon et al. 2009). Skin $\gamma \delta$ $\mathrm{T}$ cells are able to produce certain AMPs such as cathelicidins allowing antimicrobial defense (Agerberth et al. 2000). The role in antimicrobial immune responses is also attributed to skin invariant NKT cells which can recognize bacterial glycolipids (Kronenberg 2005). Self-derived glycolipids recognized by CD1d-restricted NKT cells might activate keratinocytes and induce tissue pathology such as psoriatic plaques and allergic contact dermatitis (Bonish et al. 2000; Gober et al. 2008; Nickoloff et al. 2000). Activated NKT cells can maintain high levels of TNF- $\alpha$ and increase DCs migration from the skin to draining lymph nodes in a mouse model of hypersensitivity (Gorbachev and Fairchild 2006).

\section{Conclusion and Future Remarks}

Current knowledge on immune-competent cells in the skin highlights the importance of the skin as a part of lymphatic system. The immune reactions that take place in periphery 
organ such as skin are equally important then those occurring within classical lymphoid organs in protection from the treath. In the era of vaccination and growing awareness of cancer, autoimmunity, and aging processes, the knowledge of skin immunity is of principal significance. Of high importance to our understanding of the skin immune response is the realization that this organ is characterized by diverse and low oxygen pressure (Grillon et al. 2012). Thus, more attention should be paid to environmental factors such as hypoxia, the low oxygen pressure that is divergent in different layers of the skin and governs immune reactions in this organ. Immune cells respond to low oxygen pressure in a different ways depending on the cell type. Skin hypoxia promotes the survival, recruitment, and activation of innate immune cells, whereas inhibits effector lymphocyte functions. Transcription factor hypoxia-inducible factor (HIF)- $1 \alpha$ is the key regulator of cellular adaptation to hypoxia. HIF-1 $\alpha$ plays a role in bactericidal capacity of macrophages and neutrophils. It has been shown that HIF- $1 \alpha$ regulates the production of cathelicidin by keratinocytes, thus is crucial for their antibacterial function (Peyssonnaux et al. 2008). In case of DCs, hypoxic microenvironment exerts a sharp pressure to allow pro-inflammatory and antimicrobial functions. Hypoxia has also a strong influence on sugar-binding properties by lectins which are imperious in immune recognition mechanisms, and in case of galectin-1 enhances carbohydrate binding. Expression of Langerin, a C-type lectin, creates a main characteristic for different subpopulation of skin DCs including LCs and a common antigen/pathogen recognition receptor (Stoitzner and Romani 2011). Another imperious factor that should be considered in our understanding of skin immunity is aging. Skin aging is a multifactorial process that involves defect in the function of skin immune cells. Increase in cutaneous infections and cancer becomes prominent in older humans. It has been suggested that both acquired and innate immunity are compromised with age. A substantial role in suppression of innate and acquired immune responses is attributed to Tregs. Older individuals have increased number of Tregs in normal skin. In general, older subjects are characterized by reduced cutaneous DTH responses and decreased infiltration of T cells (Castle et al. 1990; Toichi et al. 1997; Vissinga et al. 1990).

Understanding the mechanisms of skin immunity in different environmental settings will allow better therapeutic approaches both in dermatology and cosmetical industry. Recently, there is a growing interest in new and especially natural compounds with antioxidant and immunity boosting or diminishing properties that are promising in prevention from skin disease and premature aging.

\section{Compliance with ethical standards}

Conflict of interest The author declare that she has no conflict of interest.

Open Access This article is distributed under the terms of the Creative Commons Attribution 4.0 International License (http://creativecommons. org/licenses/by/4.0/), which permits unrestricted use, distribution, and reproduction in any medium, provided you give appropriate credit to the original author(s) and the source, provide a link to the Creative Commons license, and indicate if changes were made.

\section{References}

Ackermann L, Harvima IT, Pelkonen J et al (1999) Mast cells in psoriatic skin are strongly positive for interferon-gamma. Br J Dermatol 140:624-633

Agerberth B, Charo J, Werr J et al (2000) The human antimicrobial and chemotactic peptides LL-37 and alpha-defensins are expressed by specific lymphocyte and monocyte populations. Blood 96:3086-3093

Agius E, Lacy KE, Vukmanovic-Stejic M et al (2009) Decreased TNF-alpha synthesis by macrophages restricts cutaneous immunosurveillance by memory $\mathrm{CD} 4+\mathrm{T}$ cells during aging. J Exp Med 206:1929-1940

Ahmadzadeh M, Felipe-Silva A, Heemskerk B et al (2008) FOXP3 expression accurately defines the population of intratumoral regulatory $\mathrm{T}$ cells that selectively accumulate in metastatic melanoma lesions. Blood 112:4953-4960

Albanesi C, Scarponi C, Giustizieri ML et al (2005) Keratinocytes in inflammatory skin diseases. Curr Drug Targets Inflamm Allergy 4:329-334

Angel CE, Lala A, Chen CJ et al (2007) CD14+ antigen-presenting cells in human dermis are less mature than their CD1a + counterparts. Int Immunol 19:1271-1279

Auffray C, Sieweke MH, Geissmann F (2009) Blood monocytes: development, heterogeneity, and relationship with dendritic cells. Annu Rev Immunol 27:669-692

Baeke F, Korf H, Overbergh L et al (2011) The vitamin D analog, TX527, promotes a human CD4+ CD25highCD127low regulatory $\mathrm{T}$ cell profile and induces a migratory signature specific for homing to sites of inflammation. J Immunol 186:132-142

Bedoui S, Whitney PG, Waithman J et al (2009) Cross-presentation of viral and self antigens by skin-derived CD103+ dendritic cells. Nat Immunol 10:488-495

Bergstresser PR, Sullivan S, Streilein JW et al (1985) Origin and function of Thy-1+ dendritic epidermal cells in mice. J Invest Dermatol 85(1 Suppl):85s-90s

Biggs L, Yu C, Fedoric B et al (2010) Evidence that vitamin $\mathrm{D}(3)$ promotes mast cell-dependent reduction of chronic UVB-induced skin pathology in mice. J Exp Med 207:455-463

Black AP, Ardern-Jones MR, Kasprowicz V et al (2007) Human keratinocyte induction of rapid effector function in antigenspecific memory CD4+ and CD8+ T cells. Eur J Immunol 37:1485-1493

Blair RJ, Meng H, Marchese MJ et al (1997) Human mast cells stimulate vascular tube formation. Tryptase is a novel, potent angiogenic factor. J Clin Invest 99:2691-2700

Bonish B, Jullien D, Dutronc Y et al (2000) Overexpression of CD1d by keratinocytes in psoriasis and CD1d-dependent IFN-gamma production by NK-T cells. J Immunol 165:4076-4085 
Borkowski TA, Letterio JJ, Farr AG et al (1996) A role for endogenous transforming growth factor beta 1 in Langerhans cell biology: the skin of transforming growth factor beta 1 null mice is devoid of epidermal Langerhans cells. J Exp Med 184:2417-2422

Bos JD, Zonneveld I, Das PK et al (1987) The skin immune system (SIS): distribution and immunophenotype of lymphocyte subpopulations in normal human skin. $\mathbf{J}$ Invest Dermatol 88:569-573

Boyden LM, Lewis JM, Barbee SD et al (2008) Skint1, the prototype of a newly identified immunoglobulin superfamily gene cluster, positively selects epidermal gammadelta $\mathrm{T}$ cells. Nat Genet 40:656-662

Boyman O, Hefti HP, Conrad C et al (2004) Spontaneous development of psoriasis in a new animal model shows an essential role for resident $\mathrm{T}$ cells and tumor necrosis factor-alpha. J Exp Med 199:731-736

Boyman O, Conrad C, Dudli C et al (2005) Activation of dendritic antigen-presenting cells expressing common heat shock protein receptor CD91 during induction of psoriasis. $\mathrm{Br} \mathrm{J}$ Dermatol 152:1211-1218

Boyman O, Conrad C, Tonel G et al (2007) The pathogenic role of tissue-resident immune cells in psoriasis. Trends Immunol 28:51-57

Buddenkotte J, Stroh C, Engels IH et al (2005) Agonists of proteinase-activated receptor-2 stimulate upregulation of intercellular cell adhesion molecule-1 in primary human keratinocytes via activation of NF-kappa B. J Invest Dermatol 124:38-45

Byrne SN, Limon-Flores AY, Ullrich SE (2008) Mast cell migration from the skin to the draining lymph nodes upon ultraviolet irradiation represents a key step in the induction of immune suppression. J Immunol 180:4648-4655

Cai Y, Shen X, Ding C et al (2011) Pivotal role of dermal IL-17producing gammadelta $\mathrm{T}$ cells in skin inflammation. Immunity 35:596-610

Castle SC, Norman DC, Perls TT et al (1990) Analysis of cutaneous delayed-type hypersensitivity reaction and $\mathrm{T}$ cell proliferative response in elderly nursing home patients: an approach to identifying immunodeficient patients. Gerontology 36:217-229

Chacon-Salinas R, Limon-Flores AY, Chavez-Blanco AD et al (2011) Mast cell-derived IL-10 suppresses germinal center formation by affecting $\mathrm{T}$ follicular helper cell function. J Immunol 186:25-31

Clark RA (2010) Skin-resident T cells: the ups and downs of on site immunity. J Invest Dermatol 130:362-370

Clark RA, Chong B, Mirchandani N et al (2006) The vast majority of $\mathrm{CLA}+\mathrm{T}$ cells are resident in normal skin. $\mathrm{J}$ Immunol 176:4431-4439

Clark RA, Huang SJ, Murphy GF et al (2008) Human squamous cell carcinomas evade the immune response by down-regulation of vascular E-selectin and recruitment of regulatory T cells. J Exp Med 205:2221-2234

Conrad C, Boyman O, Tonel G et al (2007) Alpha1beta1 integrin is crucial for accumulation of epidermal $\mathrm{T}$ cells and the development of psoriasis. Nat Med 13:836-842

Curtis BJ, Radek KA (2012) Cholinergic regulation of keratinocyte innate immunity and permeability barrier integrity: new perspectives in epidermal immunity and disease. J Invest Dermatol 132:28-42

Dawicki W, Marshall JS (2007) New and emerging roles for mast cells in host defence. Curr Opin Immunol 19:31-38

de Jongh GJ, Zeeuwen PL, Kucharekova M et al (2005) High expression levels of keratinocyte antimicrobial proteins in psoriasis compared with atopic dermatitis. J Invest Dermatol 125:1163-1173
Demehri S, Turkoz A, Kopan R (2009) Epidermal Notch1 loss promotes skin tumorigenesis by impacting the stromal microenvironment. Cancer Cell 16:55-66

Dieu-Nosjean MC, Massacrier C, Homey B et al (2000) Macrophage inflammatory protein 3alpha is expressed at inflamed epithelial surfaces and is the most potent chemokine known in attracting Langerhans cell precursors. J Exp Med 192:705-718

Douaiher J, Succar J, Lancerotto L et al (2014) Development of mast cells and importance of their tryptase and chymase serine proteases in inflammation and wound healing. Adv Immunol 122:211-252

Dubois B, Bridon JM, Fayette J et al (1999) Dendritic cells directly modulate $\mathrm{B}$ cell growth and differentiation. J Leukoc Biol $66: 224-230$

Edele F, Molenaar R, Gutle D et al (2008) Cutting edge: instructive role of peripheral tissue cells in the imprinting of $\mathrm{T}$ cell homing receptor patterns. J Immunol 181:3745-3749

Egawa G, Kabashima K (2011) Skin as a peripheral lymphoid organ: revisiting the concept of the skin-associated lymphoid tissues. J Invest Dermatol 131:2178-2185

Feldmeyer L, Keller M, Niklaus G et al (2007) The inflammasome mediates UVB-induced activation and secretion of interleukin1beta by keratinocytes. Curr Biol 17:1140-1145

Foster CA, Yokozeki H, Rappersberger K et al (1990) Human epidermal $\mathrm{T}$ cells predominantly belong to the lineage expressing alpha/beta T cell receptor. J Exp Med 171:997-1013

Frandji P, Tkaczyk C, Oskeritzian C et al (1996) Exogenous and endogenous antigens are differentially presented by mast cells to CD4+ T lymphocytes. Eur J Immunol 26:2517-2528

Galli SJ, Tsai M (2010) Mast cells in allergy and infection: versatile effector and regulatory cells in innate and adaptive immunity. Eur J Immunol 40:1843-1851

Gebhardt T, Wakim LM, Eidsmo L et al (2009) Memory T cells in nonlymphoid tissue that provide enhanced local immunity during infection with herpes simplex virus. Nat Immunol 10:524-530

Ginhoux F, Collin MP, Bogunovic M et al (2007) Blood-derived dermal Langerin + dendritic cells survey the skin in the steady state. J Exp Med 204:3133-3146

Girardi M (2006) Immunosurveillance and immunoregulation by gammadelta T cells. J Invest Dermatol 126:25-31

Girardi M, Oppenheim DE, Steele CR et al (2001) Regulation of cutaneous malignancy by gammadelta $\mathrm{T}$ cells. Science 294:605-609

Girardi M, Lewis J, Glusac E et al (2002) Resident skin-specific gammadelta $\mathrm{T}$ cells provide local, nonredundant regulation of cutaneous inflammation. J Exp Med 195:855-867

Glitzner E, Korosec A, Brunner P et al (2014) Specific roles for dendritic cell subsets during initiation and progression of psoriasis. EMBO Mol Med 6:1312-1327

Gober MD, Fishelevich R, Zhao Y et al (2008) Human natural killer T cells infiltrate into the skin at elicitation sites of allergic contact dermatitis. J Invest Dermatol 128:1460-1469

Gomez de Aguero M, Vocanson M, Hacini-Rachinel F et al (2012) Langerhans cells protect from allergic contact dermatitis in mice by tolerizing $\mathrm{CD} 8(+) \mathrm{T}$ cells and activating Foxp3(+) regulatory T cells. J Clin Invest 122:1700-1711

Gorbachev AV, Fairchild RL (2006) Activated NKT cells increase dendritic cell migration and enhance $\mathrm{CD} 8+\mathrm{T}$ cell responses in the skin. Eur J Immunol 36:2494-2503

Grillon C, Matejuk A, Nadim M et al (2012) News on microenvironmental physioxia to revisit skin cell targeting approaches. Exp Dermatol 21:723-728

Guttman-Yassky E, Lowes MA, Fuentes-Duculan J et al (2007) Major differences in inflammatory dendritic cells and their products distinguish atopic dermatitis from psoriasis. J Allergy Clin Immunol 119:1210-1217 
Harder J, Bartels J, Christophers E et al (1997) A peptide antibiotic from human skin. Nature 387:861

Hayday A, Tigelaar R (2003) Immunoregulation in the tissues by gammadelta $T$ cells. Nat Rev Immunol 3:233-242

He S, Walls AF (1998) Human mast cell chymase induces the accumulation of neutrophils, eosinophils and other inflammatory cells in vivo. Br J Pharmacol 125:1491-1500

Henri S, Poulin LF, Tamoutounour S et al (2010) CD207+ CD103+ dermal dendritic cells cross-present keratinocyte-derived antigens irrespective of the presence of Langerhans cells. J Exp Med 207:189-206

Hershko AY, Rivera J (2010) Mast cell and T cell communication; amplification and control of adaptive immunity. Immunol Lett 128:98-104

Holtmeier W, Kabelitz D (2005) gammadelta T cells link innate and adaptive immune responses. Chem Immunol Allergy $86: 151-183$

Honda T, Egawa G, Grabbe S et al (2013) Update of immune events in the murine contact hypersensitivity model: toward the understanding of allergic contact dermatitis. J Invest Dermatol 133:303-315

Horsmanheimo L, Harvima IT, Jarvikallio A et al (1994) Mast cells are one major source of interleukin- 4 in atopic dermatitis. Br J Dermatol 131:348-353

Huang B, Lei Z, Zhang GM et al (2008) SCF-mediated mast cell infiltration and activation exacerbate the inflammation and immunosuppression in tumor microenvironment. Blood 112:1269-1279

Hunger RE, Sieling PA, Ochoa MT et al (2004) Langerhans cells utilize CD1a and Langerin to efficiently present nonpeptide antigens to $\mathrm{T}$ cells. J Clin Invest 113:701-708

Huttunen M, Naukkarinen A, Horsmanheimo M et al (2002) Transient production of stem cell factor in dermal cells but increasing expression of Kit receptor in mast cells during normal wound healing. Arch Dermatol Res 294:324-330

Iddamalgoda A, Le QT, Ito K et al (2008) Mast cell tryptase and photoaging: possible involvement in the degradation of extra cellular matrix and basement membrane proteins. Arch Dermatol Res 300(Suppl 1):S69-S76

Igyarto BZ, Haley K, Ortner D et al (2011) Skin-resident murine dendritic cell subsets promote distinct and opposing antigenspecific $\mathrm{T}$ helper cell responses. Immunity 35:260-272

Jones HE, Strid J, Osman M et al (2008) The role of beta2 integrins and lipopolysaccharide-binding protein in the phagocytosis of dead Neisseria meningitidis. Cell Microbiol 10:1634-1645

Kaminska R, Helisalmi P, Harvima RJ et al (1999) Focal dermalepidermal separation and fibronectin cleavage in basement membrane by human mast cell tryptase. J Invest Dermatol 113:567-573

Kaplan DH, Kissenpfennig A, Clausen BE (2008) Insights into Langerhans cell function from Langerhans cell ablation models. Eur J Immunol 38:2369-2376

Kaporis HG, Guttman-Yassky E, Lowes MA et al (2007) Human basal cell carcinoma is associated with Foxp3 $+\mathrm{T}$ cells in a Th2 dominant microenvironment. J Invest Dermatol 127:2391-2398

Kashem SW, Igyarto BZ, Gerami-Nejad M et al (2015) Candida albicans morphology and dendritic cell subsets determine $\mathrm{T}$ helper cell differentiation. Immunity 42:356-366

Kautz-Neu K, Noordegraaf M, Dinges S et al (2011) Langerhans cells are negative regulators of the anti-Leishmania response. J Exp Med 208:885-891

Keller M, Ruegg A, Werner S et al (2008) Active caspase-1 is a regulator of unconventional protein secretion. Cell 132:818-831

Kim BS, Wojno ED, Artis D (2013) Innate lymphoid cells and allergic inflammation. Curr Opin Immunol 25:738-744

Kitawaki T, Kadowaki N, Sugimoto N et al (2006) IgE-activated mast cells in combination with pro-inflammatory factors induce Th2promoting dendritic cells. Int Immunol 18:1789-1799
Klages K, Mayer CT, Lahl K et al (2010) Selective depletion of Foxp3+ regulatory $\mathrm{T}$ cells improves effective therapeutic vaccination against established melanoma. Cancer Res 70:7788-7799

Koch U, Radtke F (2007) Notch and cancer: a double-edged sword. Cell Mol Life Sci 64:2746-2762

Kronenberg M (2005) Toward an understanding of NKT cell biology: progress and paradoxes. Annu Rev Immunol 23:877-900

Krueger GG, Langley RG, Leonardi C et al (2007) A human interleukin-12/23 monoclonal antibody for the treatment of psoriasis. N Engl J Med 356:580-592

Kubo A, Nagao K, Yokouchi M et al (2009) External antigen uptake by Langerhans cells with reorganization of epidermal tight junction barriers. J Exp Med 206:2937-2946

Kurebayashi Y, Nagai S, Ikejiri A et al (2013) Recent advances in understanding the molecular mechanisms of the development and function of Th17 cells. Genes Cells 18:247-265

Lande R, Gregorio J, Facchinetti V et al (2007) Plasmacytoid dendritic cells sense self-DNA coupled with antimicrobial peptide. Nature 449:564-569

Larsen CP, Steinman RM, Witmer-Pack M et al (1990) Migration and maturation of Langerhans cells in skin transplants and explants. J Exp Med 172:1483-1493

Leonardi CL, Kimball AB, Papp KA et al (2008) Efficacy and safety of ustekinumab, a human interleukin-12/23 monoclonal antibody, in patients with psoriasis: 76-week results from a randomised, double-blind, placebo-controlled trial (PHOENIX 1). Lancet $371: 1665-1674$

Li T, He S (2006) Induction of IL-6 release from human T cells by PAR-1 and PAR-2 agonists. Immunol Cell Biol 84:461-466

Liang SC, Tan XY, Luxenberg DP et al (2006) Interleukin (IL)-22 and IL-17 are coexpressed by Th17 cells and cooperatively enhance expression of antimicrobial peptides. J Exp Med 203:2271-2279

Lopez-Bravo M, Ardavin C (2008) In vivo induction of immune responses to pathogens by conventional dendritic cells. Immunity 29:343-351

Lowes MA, Chamian F, Abello MV et al (2005) Increase in TNFalpha and inducible nitric oxide synthase-expressing dendritic cells in psoriasis and reduction with efalizumab (anti-CD11a). Proc Natl Acad Sci USA 102:19057-19062

Malamud V, Vaaknin A, Abramsky O et al (2003) Tryptase activates peripheral blood mononuclear cells causing the synthesis and release of TNF-alpha, IL-6 and IL-1 beta: possible relevance to multiple sclerosis. J Neuroimmunol 138:115-122

Malbec O, Daeron M (2007) The mast cell IgG receptors and their roles in tissue inflammation. Immunol Rev 217:206-221

Malissen B, Tamoutounour S, Henri S (2014) The origins and functions of dendritic cells and macrophages in the skin. Nat Rev Immunol 14:417-428

Martinon F, Mayor A, Tschopp J (2009) The inflammasomes: guardians of the body. Annu Rev Immunol 27:229-265

Matejuk A, Leng Q, Begum MD et al (2010) Peptide-based antifungal therapies against emerging infections. Drugs Future $35: 197$

Mehling A, Loser K, Varga G et al (2001) Overexpression of CD40 ligand in murine epidermis results in chronic skin inflammation and systemic autoimmunity. J Exp Med 194:615-628

Miller LS (2008) Toll-like receptors in skin. Adv Dermatol 24:71-87

Mizutani H, Schechter N, Lazarus G et al (1991) Rapid and specific conversion of precursor interleukin 1 beta (IL-1 beta) to an active IL-1 species by human mast cell chymase. J Exp Med 174:821-825

Molin D, Fischer M, Xiang Z et al (2001) Mast cells express functional CD30 ligand and are the predominant CD30L-positive cells in Hodgkin's disease. Br J Haematol 114:616-623 
Moon TC, St Laurent CD, Morris KE et al (2010) Advances in mast cell biology: new understanding of heterogeneity and function. Mucosal Immunol 3:111-128

Mora JR, Cheng G, Picarella D et al (2005) Reciprocal and dynamic control of CD8 $\mathrm{T}$ cell homing by dendritic cells from skin- and gut-associated lymphoid tissues. J Exp Med 201:303-316

Mueller SN, Gebhardt T, Carbone FR et al (2013) Memory T cell subsets, migration patterns, and tissue residence. Annu Rev Immunol 31:137-161

Nagao K, Ginhoux F, Leitner WW et al (2009) Murine epidermal Langerhans cells and Langerin-expressing dermal dendritic cells are unrelated and exhibit distinct functions. Proc Natl Acad Sci USA 106:3312-3317

Nakae S, Suto H, Kakurai M et al (2005) Mast cells enhance T cell activation: importance of mast cell-derived TNF. Proc Natl Acad Sci USA 102:6467-6472

Nakajima S, Igyarto BZ, Honda T et al (2012) Langerhans cells are critical in epicutaneous sensitization with protein antigen via thymic stromal lymphopoietin receptor signaling. J Allergy Clin Immunol 129(1048-1055):e6

Nestle FO, Conrad C, Tun-Kyi A et al (2005) Plasmacytoid predendritic cells initiate psoriasis through interferon-alpha production. J Exp Med 202:135-143

Nestle FO, Di Meglio P, Qin JZ et al (2009) Skin immune sentinels in health and disease. Nat Rev Immunol 9:679-691

Nickoloff BJ, Turka LA (1994) Immunological functions of nonprofessional antigen-presenting cells: new insights from studies of T-cell interactions with keratinocytes. Immunol Today 15:464-469

Nickoloff BJ, Bonish B, Huang BB et al (2000) Characterization of a $\mathrm{T}$ cell line bearing natural killer receptors and capable of creating psoriasis in a SCID mouse model system. J Dermatol Sci 24:212-225

Nishibu A, Ward BR, Jester JV et al (2006) Behavioral responses of epidermal Langerhans cells in situ to local pathological stimuli. J Invest Dermatol 126:787-796

Nomura T, Kabashima K, Miyachi Y (2014) The panoply of alphabetaT cells in the skin. J Dermatol Sci 76:3-9

Noordegraaf M, Flacher V, Stoitzner P et al (2010) Functional redundancy of Langerhans cells and Langerin + dermal dendritic cells in contact hypersensitivity. J Invest Dermatol 130:2752-2759

Ohl L, Mohaupt M, Czeloth N et al (2004) CCR7 governs skin dendritic cell migration under inflammatory and steady-state conditions. Immunity 21:279-288

Omoto Y, Tokime K, Yamanaka K et al (2006) Human mast cell chymase cleaves pro-IL-18 and generates a novel and biologically active IL-18 fragment. J Immunol 177:8315-8319

Ong PY, Ohtake T, Brandt C et al (2002) Endogenous antimicrobial peptides and skin infections in atopic dermatitis. N Engl J Med 347:1151-1160

Ono S, Kabashima K (2015) Proposal of inducible skin-associated lymphoid tissue (iSALT). Exp Dermatol 24:630-631

Oppenheim DE, Roberts SJ, Clarke SL et al (2005) Sustained localized expression of ligand for the activating NKG2D receptor impairs natural cytotoxicity in vivo and reduces tumor immunosurveillance. Nat Immunol 6:928-937

Pang L, Nie M, Corbett L et al (2006) Mast cell beta-tryptase selectively cleaves and RANTES and abrogates their eosinophil chemotactic activities. J Immunol 176:3788-3795

Peyssonnaux C, Boutin AT, Zinkernagel AS et al (2008) Critical role of HIF-1alpha in keratinocyte defense against bacterial infection. J Invest Dermatol 128:1964-1968

Piconese S, Gri G, Tripodo C et al (2009) Mast cells counteract regulatory T-cell suppression through interleukin-6 and OX40/OX40L axis toward Th17-cell differentiation. Blood 114:2639-2648
Pierre P, Turley SJ, Gatti E et al (1997) Developmental regulation of MHC class II transport in mouse dendritic cells. Nature 388:787-792

Poulin LF, Henri S, de Bovis B et al (2007) The dermis contains Langerin + dendritic cells that develop and function independently of epidermal Langerhans cells. J Exp Med 204:3119-3131

Richards H, Williams A, Jones E et al (2010) Novel role of regulatory $\mathrm{T}$ cells in limiting early neutrophil responses in skin. Immunology 131:583-592

Roberts SJ, Ng BY, Filler RB et al (2007) Characterizing tumorpromoting $\mathrm{T}$ cells in chemically induced cutaneous carcinogenesis. Proc Natl Acad Sci USA 104:6770-6775

Romani N, Ebner S, Tripp CH et al (2006) Epidermal Langerhans cellschanging views on their function in vivo. Immunol Lett 106:119-125

Romani N, Clausen BE, Stoitzner P (2010) Langerhans cells and more: Langerin-expressing dendritic cell subsets in the skin. Immunol Rev 234:120-141

Schauber J, Dorschner RA, Coda AB et al (2007) Injury enhances TLR2 function and antimicrobial peptide expression through a vitamin D-dependent mechanism. J Clin Invest 117:803-811

Schenkel JM, Masopust D (2014) Tissue-resident memory T cells. Immunity 41:886-897

Schwarz A, Schwarz T (2010) UVR-induced regulatory T cells switch antigen-presenting cells from a stimulatory to a regulatory phenotype. J Invest Dermatol 130:1914-1921

Serbina NV, Salazar-Mather TP, Biron CA et al (2003) TNF/iNOSproducing dendritic cells mediate innate immune defense against bacterial infection. Immunity 19:59-70

Sharlow ER, Paine CS, Babiarz L et al (2000) The protease-activated receptor-2 upregulates keratinocyte phagocytosis. J Cell Sci 113(Pt 17):3093-3101

Shklovskaya E, O'Sullivan BJ, Ng LG et al (2011) Langerhans cells are precommitted to immune tolerance induction. Proc Natl Acad Sci USA 108:18049-18054

Sigmundsdottir H, Butcher EC (2008) Environmental cues, dendritic cells and the programming of tissue-selective lymphocyte trafficking. Nat Immunol 9:981-987

Simon AK, Jones E, Richards H et al (2007) Regulatory T cells inhibit Fas ligand-induced innate and adaptive tumour immunity. Eur J Immunol 37:758-767

Skokos D, Botros HG, Demeure C et al (2003) Mast cell-derived exosomes induce phenotypic and functional maturation of dendritic cells and elicit specific immune responses in vivo. J Immunol 170:3037-3045

Stingl G, Tamaki K, Katz SI (1980) Origin and function of epidermal Langerhans cells. Immunol Rev 53:149-174

Stoitzner P, Romani N (2011) Langerin, the "catcher in the rye": an important receptor for pathogens on Langerhans cells. Eur J Immunol 41:2526-2529

Stoitzner P, Tripp CH, Douillard P et al (2005) Migratory Langerhans cells in mouse lymph nodes in steady state and inflammation. J Invest Dermatol 125:116-125

Streilein JW (1983) Skin-associated lymphoid tissues (SALT): origins and functions. J Invest Dermatol 80(Suppl):12s-16s

Suto H, Nakae S, Kakurai M et al (2006) Mast cell-associated TNF promotes dendritic cell migration. J Immunol 176:4102-4112

Tamoutounour S, Guilliams M, Montanana Sanchis F et al (2013) Origins and functional specialization of macrophages and of conventional and monocyte-derived dendritic cells in mouse skin. Immunity 39:925-938

Tang A, Amagai M, Granger LG et al (1993) Adhesion of epidermal Langerhans cells to keratinocytes mediated by E-cadherin. Nature 361:82-85

Terakawa M, Tomimori Y, Goto M et al (2006) Mast cell chymase induces expression of chemokines for neutrophils in eosinophilic EoL-1 cells and mouse peritonitis eosinophils. Eur J Pharmacol 538:175-181 
Tiemessen MM, Jagger AL, Evans HG et al (2007) CD4+ CD25+ Foxp3+ regulatory $\mathrm{T}$ cells induce alternative activation of human monocytes/macrophages. Proc Natl Acad Sci USA 104:19446-19451

Toichi E, Hanada K, Hosokawa T et al (1997) Age-related decline in humoral immunity caused by the selective loss of $\mathrm{TH}$ cells and decline in cellular immunity caused by the impaired migration of inflammatory cells without a loss of TDTH cells in SAMP1 mice. Mech Ageing Dev 99:199-217

Tomura M, Honda T, Tanizaki $\mathrm{H}$ et al (2010) Activated regulatory $\mathrm{T}$ cells are the major $\mathrm{T}$ cell type emigrating from the skin during a cutaneous immune response in mice. J Clin Invest 120:883-893

Tortola L, Rosenwald E, Abel B et al (2012) Psoriasiform dermatitis is driven by IL-36-mediated DC-keratinocyte crosstalk. J Clin Invest 122:3965-3976

Toulon A, Breton L, Taylor KR et al (2009) A role for human skinresident $\mathrm{T}$ cells in wound healing. J Exp Med 206:743-750

Tsai M, Grimbaldeston M, Galli SJ (2011) Mast cells and immunoregulation/immunomodulation. Adv Exp Med Biol 716:186-211

Valladeau J, Ravel O, Dezutter-Dambuyant C et al (2000) Langerin, a novel C-type lectin specific to Langerhans cells, is an endocytic receptor that induces the formation of Birbeck granules. Immunity 12:71-81

van der Aar AM, de Groot R, Sanchez-Hernandez M et al (2011) Cutting edge: virus selectively primes human langerhans cells for CD70 expression promoting CD8+ $\mathrm{T}$ cell responses. J Immunol 187:3488-3492

Vissinga C, Nagelkerken L, Zijlstra J et al (1990) A decreased functional capacity of CD4+ T cells underlies the impaired DTH reactivity in old mice. Mech Ageing Dev 53:127-139

Vukmanovic-Stejic M, Agius E, Booth N et al (2008) The kinetics of $\mathrm{CD} 4+$ Foxp3 $+\mathrm{T}$ cell accumulation during a human cutaneous antigen-specific memory response in vivo. $\mathrm{J}$ Clin Invest 118:3639-3650

Wang H, He S (2006) Induction of lactoferrin and IL-8 release from human neutrophils by tryptic enzymes via proteinase activated receptor-2. Cell Biol Int 30:688-697

Wang HW, Tedla N, Lloyd AR et al (1998) Mast cell activation and migration to lymph nodes during induction of an immune response in mice. J Clin Invest 102:1617-1626

Weidner N, Austen KF (1993) Heterogeneity of mast cells at multiple body sites. Fluorescent determination of avidin binding and immunofluorescent determination of chymase, tryptase, and carboxypeptidase content. Pathol Res Pract 189:156-162
Wohn C, Ober-Blobaum JL, Haak S et al (2013) Langerin(neg) conventional dendritic cells produce IL-23 to drive psoriatic plaque formation in mice. Proc Natl Acad Sci USA 110:10723-10728

Wollenberg A, Rawer HC, Schauber J (2011) Innate immunity in atopic dermatitis. Clin Rev Allergy Immunol 41:272-281

Yang Z, Zhang B, Li D et al (2010) Mast cells mobilize myeloidderived suppressor cells and Treg cells in tumor microenvironment via IL-17 pathway in murine hepatocarcinoma model. PLoS One 5:e8922

Yoshiki R, Kabashima K, Sugita K et al (2009) IL-10-producing Langerhans cells and regulatory $\mathrm{T}$ cells are responsible for depressed contact hypersensitivity in grafted skin. J Invest Dermatol 129:705-713

Yoshiki R, Kabashima K, Honda T et al (2014) IL-23 from Langerhans cells is required for the development of imiquimod-induced psoriasis-like dermatitis by induction of IL-17Aproducing gammadelta $\mathrm{T}$ cells. $\mathrm{J}$ Invest Dermatol 134:1912-1921

Zaba LC, Cardinale I, Gilleaudeau P et al (2007a) Amelioration of epidermal hyperplasia by TNF inhibition is associated with reduced Th17 responses. J Exp Med 204:3183-3194

Zaba LC, Fuentes-Duculan J, Steinman RM et al (2007b) Normal human dermis contains distinct populations of CD11c+ BDCA$1+$ dendritic cells and CD163+ FXIIIA+ macrophages. J Clin Invest 117:2517-2525

Zahner SP, Kel JM, Martina CA et al (2011) Conditional deletion of TGF-betaR1 using Langerin-Cre mice results in Langerhans cell deficiency and reduced contact hypersensitivity. J Immunol 187:5069-5076

Zanetti M (2004) Cathelicidins, multifunctional peptides of the innate immunity. J Leukoc Biol 75:39-48

Zhang W, Wu K, He W et al (2010) Transforming growth factor beta 1 plays an important role in inducing CD4(+)CD25(+) forkhead box $\mathrm{P} 3(+)$ regulatory $\mathrm{T}$ cells by mast cells. Clin Exp Immunol $161: 490-496$

Zhao W, Oskeritzian CA, Pozez AL et al (2005) Cytokine production by skin-derived mast cells: endogenous proteases are responsible for degradation of cytokines. J Immunol 175:2635-2642

Zhao W, Kepley CL, Morel PA et al (2006) Fc gamma RIIa, not Fc gamma RIIb, is constitutively and functionally expressed on skin-derived human mast cells. J Immunol 177:694-701 